\title{
bioentrepreneur
}

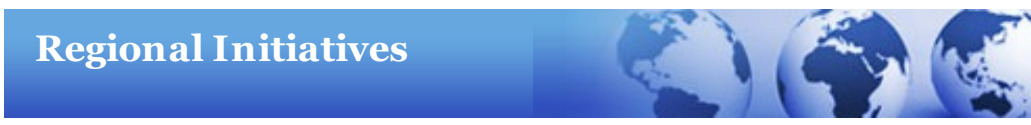

Published online: 1 December 2005, doi:10.1038/bioent893

\section{Biotech on Fashion Island?}

\section{Emily Waltz $\underline{\underline{1}}$}

Emily Waltz is an intern at Nature Biotechnology and Nature Medicine

\section{New York City is crowing about the long-awaited arrival of a new biotech park, but the city will have to overcome its image as a financial and fashion capital before it captures the interest of biotech startups.}

New York City has never been a haven for biotech companies. Startups slink away from the grandiose rents, small companies struggle to find lab space with room to grow and both strain to attract talent. But the city's plans for building a massive biotech park in Manhattan continue unabated. It's the first serious attempt to lure biotech entrepreneurs to the area-a somewhat risky endeavor that makes local investors wonder: If they build it in New York City, will biotechs come?

Venture capitalists met recently in Manhattan for a panel discussion on this and other questions about Manhattan's newest park, the East River Science Park (ERSP). The park's first phase, scheduled to be completed by 2009, will hold more than 500,000 square feet of lab and office space, a conference center and a café. Panelists included the city official who heads the project, two academic entrepreneurs and

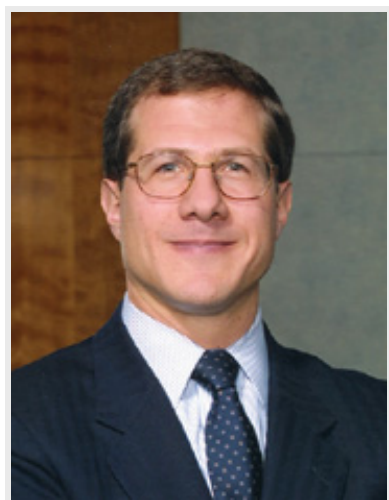

New York City Economic Development Corporation Biotech believer: Andrew Alper, president of the New York City Economic Development Corporation the park's developer.

None of the panelists harbored illusions about New York City eclipsing Boston, San Francisco, Cambridge-Oxford or Geneva any time soon. They know New York has never produced or held onto much biotech startup activity. But they agreed that a science park is at least a start in the right direction for a city full of medical researchers and money. They even got dreamy-eyed at times, describing the park as a campus within a city where offices overlook the East River and ideas seemingly waft through the halls. True, the concept is grand, but should entrepreneurs and investors add New York City to their list of hot new biotech address, or is the idea simply too far-fetched?

The ERSP is being described by boosters as a natural cluster waiting to happen. It is true, of course, that for all of its drawbacks, New York City has arguably more money, investors, top universities with medical schools, and management and research talent per square kilometer than any other spot on earth. Many of the world's largest and most active pharmaceutical partners are less than an hour's drive away.

fIf they build it in New York City, will biotechs come?

But economic planners familiar with the park project, as well as some of the panelists, say New York City might have waited too long to join the biotech cluster club. Indeed, they have voiced a common, if difficult to quantify, concern: New York isn't viewed as a biotech-savvy city-and this view just might prevent it from becoming one. When it comes to clusters, image is everything.

"It's a PR issue," John Wilkerson, co-founder of Galen Partners in New York, said during the panel discussion. "New York is known as a banking city. Most people have never thought about it as biotech."

Perhaps with good reason. New York City is home to only about 40 biotech companies, and the largest and most successful of them, ImClone, has long suffered from image problems of its own. Cambridge, Massachusetts, and San Francisco each have about five times that number of companiesand image is not a problem for either of these clusters. (It is worth noting, 
however, that Massachusetts senators recently announced a plan to invest $\$ 35$ million in the University of Massachusetts because they worry that the state will lose its biotech edge without continued infusions of tax dollars).

"There's no established [biotech] market in New York," says Joel Marcus, CEO of Alexandria Real Estate Equities, the park's developer. "Our biggest challenge is entrepreneurial talent. We need to create magnets for people to be here."

The magnet Marcus proposes is a group of buildings on a four-acre plot in pricey East Midtown, Manhattan. Pasadena, California-based Alexandria, which has in recent years positioned itself prominently in the life sciences business, already holds the lease to this Midtown property. The zoning and lease for this land did not come easily: it has been through the long zoning process and was one of the few pieces of open land the city still owns, according to Monique Salazar, an assistant vice president at the New York City Economic Development Corporation.

Alexandria will spend $\$ 300$ per square foot to develop the park, Marcus says. It will rent space to a mix of companies, research institutes, investors and shared service providers such as imaging companies, he says.

"We're making the land available to Alexandria below market value," says Andrew Alper, president of New York City Economic Development Corporation, a group running the project. The city is also contributing $\$ 10$ million to the project through the New York City Investment Fund. Alexandria is expected to pass on the subsidy to tenants, Alper says, although there is no formal agreement. "The rents will be competitive with other clusters across the country," he says.

History suggests, however, that it's going to take more than competitive rent and slick lab space to woo biotech to Manhattan. In the past, high rent and little space to grow often pushed small biotechs out of

Manhattan. "You have to have the ability to scale up quickly," says Eric Rose, founder of two biotech companies and a panelist at the discussion. "And you can't do that in Manhattan."

GYou have to have the ability to scale up quickly ... And you can't do that in Manhattan.

In the late 1990s, Ron Cohen, CEO of Hawthorn, New York-based Acorda Therapeutics, which is located just 25 miles north of New York City, tried to find lab space in Manhattan for his startup. "I'm a New York enthusiast," Cohen said, "and believe me, I tried to sublet a space. If the East River park had been up and running when we were looking, we would have stayed." He ruled out general office space because rents were high and animal facilities were hard to come by. He considered the Audubon, the biotech incubator space at Columbia University, but space was limited. Today there's a waiting list. Other incubators in New York were located outside Manhattan (see Table 1).

"At the time, I could get 5,000-10,000 square feet at the Audubon," Cohen says, "But if we met with any success and wanted to expand, we would have had to relocate and lose employees." Cohen eventually found lab space in Westchester, New York, just north of the city. Two years later, when his company grew, he doubled his square footage in just a few months.

Marcus says biotech tenants at East River Science Park will have room to expand-to a point. Once they need more than 100,000 square feet they'll need to find a new address, he says. By that point, the park's proponents hope, biotech entrepreneurs will be hooked on the neighborhood and the city in general, and, like most Manhattan residents, will find creative ways to justify their astronomical rents.

\section{Web links}

\section{Websites referenced:}

- New York City Economic Development Corporation on Biotechnology

- Alexandria Real Estate Equities, Inc.

- New York City BioScience Initiative

- Acorda Therapeutics 
Table 1: Selected incubators and tech parks in New York City regional area

\begin{tabular}{|l|l|l|}
\hline $\begin{array}{l}\text { Name } \\
\begin{array}{l}\text { Audubon Biomedical Science and } \\
\text { Technology Park }\end{array}\end{array}$ & Location & Affiliation/ownership \\
\hline $\begin{array}{l}\text { SUNY Downstate Advanced } \\
\text { Biotechnology Park }\end{array}$ & Brooklyn & Columbia University \\
\hline Broad Hollow Bioscience Park & Long Island & $\begin{array}{l}\text { SUNY downstate } \\
\text { (SUNY), Cold Spring Harbor } \\
\text { Laboratories }\end{array}$ \\
\hline $\begin{array}{l}\text { Long Island High Technology } \\
\text { Incubator }\end{array}$ & Long Island & SUNY Stony Brook \\
\hline Calverton & Long Island & SUNY Stony Brook \\
\hline Landmark at Eastview & Westchester & BMR-Landmark at Eastview LLC \\
\hline
\end{tabular}

(Source: New York Biotechnology Association)

\section{SPRINGER NATURE}

(C) 2019 Nature is part of Springer Nature. All Rights Reserved.

partner of AGORA, HINARI, OARE, INASP, ORCID, CrossRef, COUNTER and COPE 